\title{
Multilocus enzyme electrophoresis analysis of Aspergillus fumigatus strains isolated from the first clinical sample from patients with invasive aspergillosis
}

\author{
S. BeRTOUt, F. RENAUd*, T. DE MEEÜS*, M.-A. PIENS†, B. LEBEAU‡, M.-A. VIVIANI§, \\ M. MALLIÉ, J.-M. BASTIDE and the EBGA Network
}

\begin{abstract}
Laboratoire Immunologie Parasitologie MENRT UPRES EA 2413, Université Montpellier I, Faculté de Pharmacie, 15 Avenue Charles Flahault, 34060 Montpellier, Cédex 2, *Centre d'Étude sur le Polymorphisme des Micro-organismes, CEPM/UMR CNRS-IRD 9926, IRD, 911 Avenue Agropolis, BP 5045, 34032 Montpellier, Cédex 1, †Laboratoire de Mycologie Médicale et Fondamentale,Lyon, \$Département de Parasitologie-Mycologie Médicale et Moléculaire, Relation Hôtes Agents Pathogènes, Grenoble, France and $\S$ Instituto de Igiene e Medicina Preventiva, Milan Italy
\end{abstract}

\begin{abstract}
The genotypes of 50 isolates of Aspergillus fumigatus from 11 patients with invasive aspergillosis, obtained from three hospitals in different geographical areas, were determined by multilocus enzyme electrophoresis (MLEE). The study analysed the genetic polymorphism of multiple isolates from the first sample. Seven of the 14 enzymic loci studied were polymorphic, giving rise to eight different electrophoretic types. For nine of 11 patients studied, no polymorphism was observed in isolates within the first clinical sample. Analysis of genetic distance between electrophoretic types demonstrated a genetic heterogeneity within each geographical site. Moreover, some genotypes were preferentially found in a given area and this revealed a population structure within these geographical sites. Therefore, the epidemiology of $A$. fumigatus should be considered separately for each of these areas. The multiple discriminatory markers of MLEE seem to provide a powerful tool for increasing the understanding of the biology of this fungus.
\end{abstract}

\section{Introduction}

Aspergillus fumigatus is an opportunist fungal pathogen that causes high mortality among hospitalised patients [1]. It is one of the most frequent causes of nosocomial pneumonia and the mortality from infection is up to $90 \%$ [1]. It affects immunocompromised individuals suffering from severe haematological malignancies [2]. The incidence of infection with this organism has increased over the last 10 years because of the growing number of patients undergoing bone marrow or solid organ transplantation [3], and because of intensive chemotherapy and corticosteroid treatments of malignancies. A. fumigatus, commonly isolated from the environment [4], releases numerous conidia that can be inhaled by potential hosts [5]. This may induce allergic asthma, allergic bronchopulmonary aspergillosis, asper-

Received 2 July 1999; revised version received 15 Sept. 1999; accepted 20 Sept. 1999.

Corresponding author: Professor J-M. Bastide (e-mail: JeanMarie.Bastide@pharma.univ-montpl.fr). gilloma, hypersensitivity pneumonitis and invasive aspergillosis.

Epidemiological studies of aspergillosis are essential to understand the biology of this fungus [6], to understand better how it spreads [7] and to improve prevention of aspergillosis [8]. Species identification and phenotype are not sufficient to discriminate between different isolates; however, the development of DNA typing methods has increased the power of discrimination between strains $[9,10]$. Random amplified polymorphic DNA (RAPD) [11], restriction fragment length polymorphism (RFLP) analysis, moderately repetitive sequence analysis, sequence-specific DNA primer analysis [12], and restriction endonuclease analysis $[13,14]$ are routinely used to demonstrate intraspecific diversity in the genus Aspergillus. However, protein electrophoretic typing methods, such as immunoblotting and multilocus enzyme electrophoresis (MLEE), have also proved to be useful in various studies. MLEE, first used for Candida albicans [15], has provided good results for Cryptococcus [16-18] and Aspergillus [19] spp. It is a very effective typing 
method, combining both phenotypic and genotypic information.

This study determined the genetic variability at 14 putative loci of 50 isolates of $A$. fumigatus from 11 patients with invasive aspergillosis by means of MLEE. In each case, colonies from the first patient sample were typed by MLEE to investigate the genetic polymorphism of isolates within the same specimen.

\section{Materials and methods}

\section{Isolates}

The European Research Group on Biotype and Genotype of Aspergillus (EBGA) collected A. fumigatus clinical isolates at three European hospital centres. This collection was maintained by the Institute of Hygiene and Epidemiological Mycology (IHEM), Brussels, Belgium. Up to five colonies isolated from the first clinical sample, containing at least three colonies, were collected and typed. The study was performed on $50 \mathrm{~A}$. fumigatus isolates from 11 patients suffering from haematological malignancies with or without neutropenia. Clinical, radiological and mycological investigations were carried out at three hospital centres (Lyon, France; Grenoble, France; Milan, Italy). Isolates from these hospital centres and IHEM were identified by classical techniques based on conventional morphological identification. The origins of the isolates of A. fumigatus are summarised in Table 1.

\section{Preparation of culture lysates}

The A. fumigatus cultures were grown on a gyratory shaker at $150 \mathrm{rpm}$ in 500-ml flasks containing $150 \mathrm{ml}$ of Sabouraud liquid medium ( $\mathrm{pH} 8$ ) at $37^{\circ} \mathrm{C}$ for 4 days. The mycelial growth was harvested and washed with $1 \mathrm{M}$ phospate-buffered saline (PBS). Mycelial fragments were disrupted mechanically at $4^{\circ} \mathrm{C}$ by the glass bead method $(0.25 \mathrm{~mm}$ diameter $)$ for $2 \mathrm{~min}$ in a Science Tech MSK homogenizer (B. Braun, Melsungen, Germany). Cell debris was removed by centrifugation at $4000 \mathrm{~g}$ for $30 \mathrm{~min}$ at $0^{\circ} \mathrm{C}$. The supernate of each lysate was stored in divided volumes at $-20^{\circ} \mathrm{C}$ before use in MLEE.

\section{MLEE}

Starch gel electrophoresis and specific enzyme staining were performed as described previously $[15,16,19,20]$. In this study, 14 enzymic systems were tested: peptidase 1 (PEP 1, EC 3.4.11, substrate, Val-Leu); peptidase 2 (PEP 2, EC 3.4.11, substrate, Leu-Gly-Gly); peptidase 4 (PEP 4, EC 3.4.11, substrate, Leu-Ala; peptidase 3 (PEP 3, EC 3.4.11, substrate, Phe-Pro); peptidase 5 (PEP 5, EC 3.4.11, substrate, Lys-Leu); glucose phosphate isomerase (GPI, EC 5.3.1.9); malate dehydrogenase $(\mathrm{MDH}, \quad$ EC 1.1.1.37); malico-enzyme (ME, EC 1.1.1.40); aspartate-amino-transferase (AAT, EC 2.6.1.1); glucose-6-phosphate dehydrogenase $\left(\mathrm{G}_{6} \mathrm{PD}\right.$, EC 1.1.1.27); phosphoglucomutase (PGM, EC 2.7.5.1), 6-phosphogluconate dehydrogenase (PGD, EC 1.1.1.43).

Alleles were numbered in decreasing order of their anodal mobility. Each isolate was characterised for the various polymorphic enzyme-encoding loci. Distinct multilocus variants were designated an electrophoretic type (ET).

\section{Calculation of genetic distances}

Genetic distances were calculated to quantify genetic divergences between the strains observed by allelic frequencies. Corrected genetic distance (D) is given by the equation:

Table 1. Characteristics of the strains of A. fumigatus studied

\begin{tabular}{|c|c|c|c|c|c|c|}
\hline Patient & Underlying disease & Sample & Date of sampling & Neutropenia & IHEM no. & Origin \\
\hline $\mathrm{A}$ & Lymphoma & BAL & $16 / 11 / 94$ & Yes & $9378-9382$ & Lyon \\
\hline $\mathrm{B}$ & Lymphoma & BAL & $17 / 2 / 95$ & Yes & $9508-9512$ & Lyon \\
\hline $\mathrm{C}$ & $\begin{array}{l}\text { Lymphoma } \\
\text { Leukaemia } \\
\text { Solid tumour }\end{array}$ & Sputum & $10 / 1 / 95$ & Yes & $9447-9451$ & Lyon \\
\hline $\mathrm{D}$ & Bone marrow transplant & BAL & $4 / 4 / 95$ & Yes & $9595-9598$ & Lyon \\
\hline 1 & Lymphoma & BA & $21 / 4 / 94$ & Yes & $9025-9029$ & Milan \\
\hline 2 & $\begin{array}{l}\text { Long-term corticosteroid II } \\
\text { therapy }\end{array}$ & $\begin{array}{l}\text { Rhinopharyngeal } \\
\text { aspirate }\end{array}$ & $24 / 10 / 97$ & Yes & $14202-14206$ & Milan \\
\hline 3 & Long-term corticotherapy & BA & $9 / 5 / 96$ & No & $10054-10056$ & Milan \\
\hline$\alpha$ & $\begin{array}{l}\text { Lymphoma } \\
\text { Bone marrow transplant }\end{array}$ & BAL & $13 / 1 / 95$ & Yes & $9418-9420$ & Grenoble \\
\hline$\beta$ & $\begin{array}{l}\text { Leukaemia } \\
\text { Long-term corticosteroid therapy }\end{array}$ & BAL & $4 / 10 / 94$ & Yes & $9347-9351$ & Grenoble \\
\hline$\chi$ & $\begin{array}{l}\text { Lymphoma } \\
\text { Kidney transplant }\end{array}$ & BA & $29 / 5 / 95$ & Yes & $9720-9724$ & Grenoble \\
\hline$\delta$ & Leukaemia & BA & $18 / 4 / 95$ & Yes & $9600-9604$ & Grenoble \\
\hline
\end{tabular}

BAL, bronchoalveolar lavage; BA, brochial aspiration. 


$$
D^{2}=4 * \frac{\sum_{\mathrm{m}} 1-\left(\sqrt{\mathrm{p}_{1 \mathrm{mi}}} \sqrt{\mathrm{p}_{2 \mathrm{mi}}}\right)}{\sum \mathrm{a}_{\mathrm{m}}-1}
$$

Where $\mathbf{m}$ represents the locus number, $\mathbf{p}_{\text {nmi }}$ frequency of allele $\mathbf{i}$ for locus $\mathbf{m}$ in the population $\mathbf{n}$ and $\mathbf{a}_{\mathrm{m}}$, the number of alleles at locus $\mathbf{m}[21,22]$.

\section{Results}

MLEE gave reproducible results; identical results were obtained when isolates were subcultured several times on Sabouraud medium and when electrophoresis was performed on samples from every fourth isolate passage.

\section{Genetic diversity}

Seven loci were polymorphic in the 50 strains examined, each with two alleles. The study identified 14 alleles giving eight different ET. The remaining seven profiles (Pep B, Pep C, Pep E, Mdh, Me, Hk, Mpi) were highly conserved. One locus (Pgm) displayed a heterozygous pattern phenotype.

Strain diversity within the same sample Different colonies sampled from the same patient displayed the same multilocus pattern in nine of 11 patients. In two patients the infection was clearly caused by two different strains. For these two patients (patient 1 and patient $\alpha$ ), strains differed from the others by one allele at the locus Fum. This difference separates ET3 and ET5 in Milan and ET7 and ET8 in Grenoble (Table 2). In other cases, only one genotype was found for each patient.

Strain diversity inside the same area. There was extensive genetic variability within geographical sites. In Grenoble, three different genotypes were found from four patients studied; pairs of ETs differed by one-totwo loci (Table 3). In Milan, three different genotypes were found from three patients; pairs of ET differed by one-to-three loci (Table 3). In Lyon, three different genotypes were identified from four patients studied and pairs of ET differed by two-to-four loci (Table 3).

Strain diversity between geographical sites. Some genotypes were preferentially found in a given area. ET1, ET7 and ET8 were found only in Grenoble; ET5 and ET6 only in Milan and ET2 and ET4 only in Lyon. Only ET3 was found in both Lyon and Milan. Moreover, GPI 2 allele was found only in strains from Grenoble and Pep1-2 and Pep4-2 alleles were found only in strains from Lyon (Table 2). These results suggest the existence of extensive intra- and inter-site heterogeneity and, thus, a relative independence of each area.
There is a lack of correlation between the genotype of each of the strains studied and the geographic distance. Genetic distances between ET from the two nearest cities (Lyon and Grenoble) were greater than between ET from Lyon and Milan (Table 2). This was shown by differences between pairs of ET (three-to-seven between Lyon and Grenoble and three-to-five between Lyon and Milan) (Table 3).

\section{Discussion}

MLEE is one of numerous typing methods developed for the differentiation of A. fumigatus isolates. It has a relatively high degree of discriminatory power, but also allows assessment of the structure and differentiation of the sample studied, including its genetic diversity $[15,16,19]$. It was used as the main technique in this study because is is considered to be a useful epidemiological tool for increasing understanding of the biology of A. fumigatus.

A genetic analysis of 50 strains of A. fumigatus from three geographical areas was performed. Some studies have reported an extensive variation in this fungus. Rinyu et al. found that 61 strains could be classified in 19 groups, by analysing only seven enzymic systems [23]. Matsuda et al. distinguished 14 ETs within 34 strains, with only three polymorphic enzymic systems [24]. Rodriguez et al. found 48 allelic combinations within 71 isolates [19]. In the present study, the level of diversity observed was less than that reported in the above studies. This was due to the strong homogeneity of samples studied, and is in agreement with studies from Radford et al., who found 11 distinct DNA types among a total of 119 isolates [25]. In the present study, for each patient the specimen chosen for typing was the first sample, containing three-to-five colonies. The study demonstrated that there was a strong homogeneity within the same specimen with strains exhibiting the same multilocus enzymic profile. Only two patients were shown to have an infection caused by two different strains. The difference between these strains was due to only one allele at the locus Fum (Table 2). This might be due to a recent mutation and this result is very important for the investigation of the effect of therapy on these strains, as mutation can interfere with the treatment of infections by some strains. If $A$. fumigatus is considered to be diploid [19], two alleles would be affected by the same mutation, and this type of mutation occurs rarely. However, if A. fumigatus is considered to be haploid [26], only one allele can be affected by this mutation. This second possibility is the most likely. The apparently heterozygous pattern at the locus Pgm may be due to a duplication of this gene. However, in most cases, only one strain was responsible for the infection, regardless of the geographical location. The present study focused on human clinical isolates and is in agreement with some other studies $[25,27]$, which showed that usually only one strain of 
Table 2. Allelic profiles* and origin of isolates of A. fumigatus

\begin{tabular}{|c|c|c|c|c|c|c|c|c|c|c|c|c|c|c|c|c|}
\hline \multirow{2}{*}{$\begin{array}{l}\text { Patient and } \\
\text { IHEM no. }\end{array}$} & \multirow[b]{2}{*}{ Origin } & \multicolumn{14}{|c|}{ Alleles at the indicated enzyme locus ${ }^{\dagger \dagger}$} & \multirow[b]{2}{*}{ ET no } \\
\hline & & Pep 1 & Pep 2 & Pep 3 & Pep 4 & Pep 5 & Aat & $\mathrm{Me}$ & Mdh & $\mathrm{Hk}$ & Fum & Gpi & Mpi & Pgm & Pgd & \\
\hline A 9378 & \multirow[t]{19}{*}{ Lyon } & $1 / 1$ & $1 / 1$ & $1 / 1$ & $1 / 1$ & $1 / 1$ & $1 / 1$ & $1 / 1$ & $1 / 1$ & $1 / 1$ & $1 / 1$ & $1 / 1$ & $1 / 1$ & $1 / 1$ & $1 / 1$ & 3 \\
\hline 9379 & & $1 / 1$ & $1 / 1$ & $1 / 1$ & $1 / 1$ & $1 / 1$ & $1 / 1$ & $1 / 1$ & $1 / 1$ & $1 / 1$ & $1 / 1$ & $1 / 1$ & $1 / 1$ & $1 / 1$ & $1 / 1$ & 3 \\
\hline 9380 & & $1 / 1$ & $1 / 1$ & $1 / 1$ & $1 / 1$ & $1 / 1$ & $1 / 1$ & $1 / 1$ & $1 / 1$ & $1 / 1$ & $1 / 1$ & $1 / 1$ & $1 / 1$ & $1 / 1$ & $1 / 1$ & 3 \\
\hline 9381 & & $1 / 1$ & $1 / 1$ & $1 / 1$ & $1 / 1$ & $1 / 1$ & $1 / 1$ & $1 / 1$ & $1 / 1$ & $1 / 1$ & $1 / 1$ & $1 / 1$ & $1 / 1$ & $1 / 1$ & $1 / 1$ & 3 \\
\hline 9382 & & $1 / 1$ & $1 / 1$ & $1 / 1$ & $1 / 1$ & $1 / 1$ & $1 / 1$ & $1 / 1$ & $1 / 1$ & $1 / 1$ & $1 / 1$ & $1 / 1$ & $1 / 1$ & $1 / 1$ & $1 / 1$ & 3 \\
\hline В 9508 & & $2 / 2$ & $1 / 1$ & $1 / 1$ & $2 / 2$ & $1 / 1$ & $1 / 1$ & $1 / 1$ & $1 / 1$ & $1 / 1$ & $1 / 1$ & $1 / 1$ & $1 / 1$ & $1 / 1$ & $1 / 1$ & 4 \\
\hline 9509 & & $2 / 2$ & $1 / 1$ & $1 / 1$ & $2 / 2$ & $1 / 1$ & $1 / 1$ & $1 / 1$ & $1 / 1$ & $1 / 1$ & $1 / 1$ & $1 / 1$ & $1 / 1$ & $1 / 1$ & $1 / 1$ & 4 \\
\hline 9510 & & $2 / 2$ & $1 / 1$ & $1 / 1$ & $2 / 2$ & $1 / 1$ & $1 / 1$ & $1 / 1$ & $1 / 1$ & $1 / 1$ & $1 / 1$ & $1 / 1$ & $1 / 1$ & $1 / 1$ & $1 / 1$ & 4 \\
\hline 9511 & & $2 / 2$ & $1 / 1$ & $1 / 1$ & $2 / 2$ & $1 / 1$ & $1 / 1$ & $1 / 1$ & $1 / 1$ & $1 / 1$ & $1 / 1$ & $1 / 1$ & $1 / 1$ & $1 / 1$ & $1 / 1$ & 4 \\
\hline 9512 & & $2 / 2$ & $1 / 1$ & $1 / 1$ & $2 / 2$ & $1 / 1$ & $1 / 1$ & $1 / 1$ & $1 / 1$ & $1 / 1$ & $1 / 1$ & $1 / 1$ & $1 / 1$ & $1 / 1$ & $1 / 1$ & 4 \\
\hline C 9447 & & $1 / 1$ & $1 / 1$ & $1 / 1$ & $1 / 1$ & $1 / 1$ & $1 / 1$ & $1 / 1$ & $1 / 1$ & $1 / 1$ & $1 / 1$ & $1 / 1$ & $1 / 1$ & $1 / 1$ & $1 / 1$ & 3 \\
\hline 9448 & & $1 / 1$ & $1 / 1$ & $1 / 1$ & $1 / 1$ & $1 / 1$ & $1 / 1$ & $1 / 1$ & $1 / 1$ & $1 / 1$ & $1 / 1$ & $1 / 1$ & $1 / 1$ & $1 / 1$ & $1 / 1$ & 3 \\
\hline 9449 & & $1 / 1$ & $1 / 1$ & $1 / 1$ & $1 / 1$ & $1 / 1$ & $1 / 1$ & $1 / 1$ & $1 / 1$ & $1 / 1$ & $1 / 1$ & $1 / 1$ & $1 / 1$ & $1 / 1$ & $1 / 1$ & 3 \\
\hline 9450 & & $1 / 1$ & $1 / 1$ & $1 / 1$ & $1 / 1$ & $1 / 1$ & $1 / 1$ & $1 / 1$ & $1 / 1$ & $1 / 1$ & $1 / 1$ & $1 / 1$ & $1 / 1$ & $1 / 1$ & $1 / 1$ & 3 \\
\hline 9451 & & $1 / 1$ & $1 / 1$ & $1 / 1$ & $1 / 1$ & $1 / 1$ & $1 / 1$ & $1 / 1$ & $1 / 1$ & $1 / 1$ & $1 / 1$ & $1 / 1$ & $1 / 1$ & $1 / 1$ & $1 / 1$ & 3 \\
\hline D 9595 & & $2 / 2$ & $1 / 1$ & $1 / 1$ & $2 / 2$ & $1 / 1$ & $2 / 2$ & $1 / 1$ & $1 / 1$ & $1 / 1$ & $1 / 1$ & $1 / 1$ & $1 / 1$ & $1 / 2$ & $1 / 1$ & 2 \\
\hline 9596 & & $2 / 2$ & $1 / 1$ & $1 / 1$ & $2 / 2$ & $1 / 1$ & $2 / 2$ & $1 / 1$ & $1 / 1$ & $1 / 1$ & $1 / 1$ & $1 / 1$ & $1 / 1$ & $1 / 2$ & $1 / 1$ & 2 \\
\hline 9597 & & $2 / 2$ & $1 / 1$ & $1 / 1$ & $2 / 2$ & $1 / 1$ & $2 / 2$ & $1 / 1$ & $1 / 1$ & $1 / 1$ & $1 / 1$ & $1 / 1$ & $1 / 1$ & $1 / 2$ & $1 / 1$ & 2 \\
\hline 9598 & & $2 / 2$ & $1 / 1$ & $1 / 1$ & $2 / 2$ & $1 / 1$ & $2 / 2$ & $1 / 1$ & $1 / 1$ & $1 / 1$ & $1 / 1$ & $1 / 1$ & $1 / 1$ & $1 / 2$ & $1 / 1$ & 2 \\
\hline 19025 & \multirow[t]{13}{*}{ Milan } & $1 / 1$ & $1 / 1$ & $1 / 1$ & $1 / 1$ & $1 / 1$ & $1 / 1$ & $1 / 1$ & $1 / 1$ & $1 / 1$ & $1 / 1$ & $1 / 1$ & $1 / 1$ & $1 / 1$ & $1 / 1$ & 3 \\
\hline 9026 & & $1 / 1$ & $1 / 1$ & $1 / 1$ & $1 / 1$ & $1 / 1$ & $1 / 1$ & $1 / 1$ & $1 / 1$ & $1 / 1$ & $1 / 1$ & $1 / 1$ & $1 / 1$ & $1 / 1$ & $1 / 1$ & 3 \\
\hline 9027 & & $1 / 1$ & $1 / 1$ & $1 / 1$ & $1 / 1$ & $1 / 1$ & $1 / 1$ & $1 / 1$ & $1 / 1$ & $1 / 1$ & $2 / 2$ & $1 / 1$ & $1 / 1$ & $1 / 1$ & $1 / 1$ & 5 \\
\hline 9028 & & $1 / 1$ & $1 / 1$ & $1 / 1$ & $1 / 1$ & $1 / 1$ & $1 / 1$ & $1 / 1$ & $1 / 1$ & $1 / 1$ & $1 / 1$ & $1 / 1$ & $1 / 1$ & $1 / 1$ & $1 / 1$ & 3 \\
\hline 9029 & & $1 / 1$ & $1 / 1$ & $1 / 1$ & $1 / 1$ & $1 / 1$ & $1 / 1$ & $1 / 1$ & $1 / 1$ & $1 / 1$ & $1 / 1$ & $1 / 1$ & $1 / 1$ & $1 / 1$ & $1 / 1$ & 3 \\
\hline 214202 & & $1 / 1$ & $1 / 1$ & $1 / 1$ & $1 / 1$ & $1 / 1$ & $2 / 2$ & $1 / 1$ & $1 / 1$ & $1 / 1$ & $1 / 1$ & $1 / 1$ & $1 / 1$ & $1 / 2$ & $1 / 1$ & 6 \\
\hline 14203 & & $1 / 1$ & $1 / 1$ & $1 / 1$ & $1 / 1$ & $1 / 1$ & $2 / 2$ & $1 / 1$ & $1 / 1$ & $1 / 1$ & $1 / 1$ & $1 / 1$ & $1 / 1$ & $1 / 2$ & $1 / 1$ & 6 \\
\hline 14204 & & $1 / 1$ & $1 / 1$ & $1 / 1$ & $1 / 1$ & $1 / 1$ & $2 / 2$ & $1 / 1$ & $1 / 1$ & $1 / 1$ & $1 / 1$ & $1 / 1$ & $1 / 1$ & $1 / 2$ & $1 / 1$ & 6 \\
\hline 14205 & & $1 / 1$ & $1 / 1$ & $1 / 1$ & $1 / 1$ & $1 / 1$ & $2 / 2$ & $1 / 1$ & $1 / 1$ & $1 / 1$ & $1 / 1$ & $1 / 1$ & $1 / 1$ & $1 / 2$ & $1 / 1$ & 6 \\
\hline 14206 & & $1 / 1$ & $1 / 1$ & $1 / 1$ & $1 / 1$ & $1 / 1$ & $2 / 2$ & $1 / 1$ & $1 / 1$ & $1 / 1$ & $1 / 1$ & $1 / 1$ & $1 / 1$ & $1 / 2$ & $1 / 1$ & 6 \\
\hline 310054 & & $1 / 1$ & $1 / 1$ & $1 / 1$ & $1 / 1$ & $1 / 1$ & $1 / 1$ & $1 / 1$ & $1 / 1$ & $1 / 1$ & $1 / 1$ & $1 / 1$ & $1 / 1$ & $1 / 1$ & $1 / 1$ & 3 \\
\hline 10055 & & $1 / 1$ & $1 / 1$ & $1 / 1$ & $1 / 1$ & $1 / 1$ & $1 / 1$ & $1 / 1$ & $1 / 1$ & $1 / 1$ & $1 / 1$ & $1 / 1$ & $1 / 1$ & $1 / 1$ & $1 / 1$ & 3 \\
\hline 10056 & & $1 / 1$ & $1 / 1$ & $1 / 1$ & $1 / 1$ & $1 / 1$ & $1 / 1$ & $1 / 1$ & $1 / 1$ & $1 / 1$ & $1 / 1$ & $1 / 1$ & $1 / 1$ & $1 / 1$ & $1 / 1$ & 3 \\
\hline
\end{tabular}


Table 2. (cont.)

\begin{tabular}{|c|c|c|c|c|c|c|c|c|c|c|c|c|c|c|c|c|}
\hline \multirow{2}{*}{$\begin{array}{l}\text { Patient and } \\
\text { IHEM no. }\end{array}$} & \multirow[b]{2}{*}{ Origin } & \multicolumn{14}{|c|}{ Alleles at the indicated enzyme locus ${ }^{\dagger+}$} & \multirow[b]{2}{*}{ ET no. } \\
\hline & & Pep 1 & Pep 2 & Pep 3 & Pep 4 & Pep 5 & Aat & $\mathrm{Me}$ & Mdh & $\mathrm{Hk}$ & Fum & Gpi & Mpi & Pgm & Pgd & \\
\hline $\begin{array}{r}\alpha 9418 \\
9419 \\
9420\end{array}$ & Grenoble & $\begin{array}{l}1 / 1 \\
1 / 1 \\
1 / 1\end{array}$ & $\begin{array}{l}1 / 1 \\
1 / 1 \\
1 / 1\end{array}$ & $\begin{array}{l}1 / 1 \\
1 / 1 \\
1 / 1\end{array}$ & $\begin{array}{l}1 / 1 \\
1 / 1 \\
1 / 1\end{array}$ & $\begin{array}{l}1 / 1 \\
1 / 1 \\
1 / 1\end{array}$ & $\begin{array}{l}1 / 1 \\
1 / 1 \\
1 / 1\end{array}$ & $\begin{array}{l}1 / 1 \\
1 / 1 \\
1 / 1\end{array}$ & $\begin{array}{l}1 / 1 \\
1 / 1 \\
1 / 1\end{array}$ & $\begin{array}{l}1 / 1 \\
1 / 1 \\
1 / 1\end{array}$ & $\begin{array}{l}1 / 1 \\
2 / 2 \\
1 / 1\end{array}$ & $\begin{array}{l}2 / 2 \\
2 / 2 \\
2 / 2\end{array}$ & $\begin{array}{l}1 / 1 \\
1 / 1 \\
1 / 1\end{array}$ & $\begin{array}{l}1 / 1 \\
1 / 1 \\
1 / 1\end{array}$ & $\begin{array}{l}2 / 2 \\
2 / 2 \\
2 / 2\end{array}$ & $\begin{array}{l}7 \\
8 \\
7\end{array}$ \\
\hline $\begin{array}{r}\beta 9347 \\
9348 \\
9349 \\
9350 \\
9351\end{array}$ & & $\begin{array}{l}1 / 1 \\
1 / 1 \\
1 / 1 \\
1 / 1 \\
1 / 1\end{array}$ & $\begin{array}{l}1 / 1 \\
1 / 1 \\
1 / 1 \\
1 / 1 \\
1 / 1\end{array}$ & $\begin{array}{l}1 / 1 \\
1 / 1 \\
1 / 1 \\
1 / 1 \\
1 / 1\end{array}$ & $\begin{array}{l}1 / 1 \\
1 / 1 \\
1 / 1 \\
1 / 1 \\
1 / 1\end{array}$ & $\begin{array}{l}1 / 1 \\
1 / 1 \\
1 / 1 \\
1 / 1 \\
1 / 1\end{array}$ & $\begin{array}{l}1 / 1 \\
1 / 1 \\
1 / 1 \\
1 / 1 \\
1 / 1\end{array}$ & $\begin{array}{l}1 / 1 \\
1 / 1 \\
1 / 1 \\
1 / 1 \\
1 / 1\end{array}$ & $\begin{array}{l}1 / 1 \\
1 / 1 \\
1 / 1 \\
1 / 1 \\
1 / 1\end{array}$ & $\begin{array}{l}1 / 1 \\
1 / 1 \\
1 / 1 \\
1 / 1 \\
1 / 1\end{array}$ & $\begin{array}{l}1 / 1 \\
1 / 1 \\
1 / 1 \\
1 / 1 \\
1 / 1\end{array}$ & $\begin{array}{l}2 / 2 \\
2 / 2 \\
2 / 2 \\
2 / 2 \\
2 / 2\end{array}$ & $\begin{array}{l}1 / 1 \\
1 / 1 \\
1 / 1 \\
1 / 1 \\
1 / 1\end{array}$ & $\begin{array}{l}1 / 1 \\
1 / 1 \\
1 / 1 \\
1 / 1 \\
1 / 1\end{array}$ & $\begin{array}{l}1 / 1 \\
1 / 1 \\
1 / 1 \\
1 / 1 \\
1 / 1\end{array}$ & $\begin{array}{l}1 \\
1 \\
1 \\
1 \\
1\end{array}$ \\
\hline $\begin{array}{r}\chi 9720 \\
9721 \\
9722 \\
9723 \\
9724\end{array}$ & & $\begin{array}{l}1 / 1 \\
1 / 1 \\
1 / 1 \\
1 / 1 \\
1 / 1\end{array}$ & $\begin{array}{l}1 / 1 \\
1 / 1 \\
1 / 1 \\
1 / 1 \\
1 / 1\end{array}$ & $\begin{array}{l}1 / 1 \\
1 / 1 \\
1 / 1 \\
1 / 1 \\
1 / 1\end{array}$ & $\begin{array}{l}1 / 1 \\
1 / 1 \\
1 / 1 \\
1 / 1 \\
1 / 1\end{array}$ & $\begin{array}{l}1 / 1 \\
1 / 1 \\
1 / 1 \\
1 / 1 \\
1 / 1\end{array}$ & $\begin{array}{l}1 / 1 \\
1 / 1 \\
1 / 1 \\
1 / 1 \\
1 / 1\end{array}$ & $\begin{array}{l}1 / 1 \\
1 / 1 \\
1 / 1 \\
1 / 1 \\
1 / 1\end{array}$ & $\begin{array}{l}1 / 1 \\
1 / 1 \\
1 / 1 \\
1 / 1 \\
1 / 1\end{array}$ & $\begin{array}{l}1 / 1 \\
1 / 1 \\
1 / 1 \\
1 / 1 \\
1 / 1\end{array}$ & $\begin{array}{l}1 / 1 \\
1 / 1 \\
1 / 1 \\
1 / 1 \\
1 / 1\end{array}$ & $\begin{array}{l}2 / 2 \\
2 / 2 \\
2 / 2 \\
2 / 2 \\
2 / 2\end{array}$ & $\begin{array}{l}1 / 1 \\
1 / 1 \\
1 / 1 \\
1 / 1 \\
1 / 1\end{array}$ & $\begin{array}{l}1 / 1 \\
1 / 1 \\
1 / 1 \\
1 / 1 \\
1 / 1\end{array}$ & $\begin{array}{l}1 / 1 \\
1 / 1 \\
1 / 1 \\
1 / 1 \\
1 / 1\end{array}$ & $\begin{array}{l}1 \\
1 \\
1 \\
1 \\
1\end{array}$ \\
\hline $\begin{array}{r}\delta 9600 \\
9601 \\
9602 \\
9603 \\
9604\end{array}$ & & $\begin{array}{l}1 / 1 \\
1 / 1 \\
1 / 1 \\
1 / 1 \\
1 / 1\end{array}$ & $\begin{array}{l}1 / 1 \\
1 / 1 \\
1 / 1 \\
1 / 1 \\
1 / 1\end{array}$ & $\begin{array}{l}1 / 1 \\
1 / 1 \\
1 / 1 \\
1 / 1 \\
1 / 1\end{array}$ & $\begin{array}{l}1 / 1 \\
1 / 1 \\
1 / 1 \\
1 / 1 \\
1 / 1\end{array}$ & $\begin{array}{l}1 / 1 \\
1 / 1 \\
1 / 1 \\
1 / 1 \\
1 / 1\end{array}$ & $\begin{array}{l}1 / 1 \\
1 / 1 \\
1 / 1 \\
1 / 1 \\
1 / 1\end{array}$ & $\begin{array}{l}1 / 1 \\
1 / 1 \\
1 / 1 \\
1 / 1 \\
1 / 1\end{array}$ & $\begin{array}{l}1 / 1 \\
1 / 1 \\
1 / 1 \\
1 / 1 \\
1 / 1\end{array}$ & $\begin{array}{l}1 / 1 \\
1 / 1 \\
1 / 1 \\
1 / 1 \\
1 / 1\end{array}$ & $\begin{array}{l}1 / 1 \\
1 / 1 \\
1 / 1 \\
1 / 1 \\
1 / 1\end{array}$ & $\begin{array}{l}2 / 2 \\
2 / 2 \\
2 / 2 \\
2 / 2 \\
2 / 2\end{array}$ & $\begin{array}{l}1 / 1 \\
1 / 1 \\
1 / 1 \\
1 / 1 \\
1 / 1\end{array}$ & $\begin{array}{l}1 / 1 \\
1 / 1 \\
1 / 1 \\
1 / 1 \\
1 / 1\end{array}$ & $\begin{array}{l}1 / 1 \\
1 / 1 \\
1 / 1 \\
1 / 1 \\
1 / 1\end{array}$ & $\begin{array}{l}1 \\
1 \\
1 \\
1 \\
1\end{array}$ \\
\hline
\end{tabular}

${ }^{*}$ Results of four independent experiments for each enzymic system.

${ }^{\dagger}$ For abbreviations, see Materials and methods. 
Table 3. Nei's genetic distances (lower left matrix) and number of loci showing different alleles (upper right matrix) between the different A. fumigatus ET analysed

\begin{tabular}{lcccccccc}
\hline & ET1 & ET2 & ET3 & ET4 & ET5 & ET6 & ET7 & ET8 \\
\hline ET1 & - & 5 & 1 & 3 & 2 & 3 & 1 & 2 \\
ET2 & 0.370 & - & 4 & 2 & 5 & 3 & 6 & 7 \\
ET3 & 0.074 & 0.269 & - & 2 & 1 & 2 & 2 & 3 \\
ET4 & 0.241 & 0.095 & 0.154 & - & 3 & 4 & 4 & 5 \\
ET5 & 0.154 & 0.370 & 0.074 & 0.241 & - & 3 & 3 & 2 \\
ET6 & 0.179 & 0.160 & 0.095 & 0.269 & 0.179 & - & 4 & 5 \\
ET7 & 0.074 & 0.481 & 0.154 & 0.336 & 0.241 & 0.269 & - & 1 \\
ET8 & 0.154 & 0.606 & 0.241 & 0.442 & 0.154 & 0.370 & 0.074 & - \\
\hline
\end{tabular}

A. fumigatus is responsible for the infection of a particular patient. However, some authors found that some patients may be infected by several different strains in the late stages of the infection $[25,28]$. Thus, the best strategy for epidemiological studies to determine the source of an infection is to type several colonies within the same sample.

The present study demonstrated that infection by $A$. fumigatus is very different from that caused by $C$. albicans. Multiple strains of $C$. albicans have been found in the oral cavity of an individual patient in the early stage of infection $[29,30]$, and only one strain becomes predominant during an infection. In contrast, only one strain of A. fumigatus is responsible for the infection in most cases of invasive aspergillosis. Multiple strain genotypes can be found post-mortem, or in cases of lung transplant patients suffering from necrotising aspergillosis, bronchitis aspergillosis, or bronchial colonisation [12]. These data are very important for determining the mechanism of infection of this opportunist fungus and proves that the mechanisms of A. fumigatus and C. albicans are quite different.

Although the number of strains studied was too small to provide phylogenetic information, the data (Tables 1 and 2) demonstrate the relative heterogeneity between strains within each geographical site. Most ETs are closely related within a sampling site (ET1, ET7, ET8 in Grenoble; ET5, ET6 in Milan; ET2, ET4 in Lyon). Moreover, these data suggest that the global diversity is less extensive within each geographical site than between two different sites. This suggests that strains may be adapted to a particular hospital environment and that the epidemiology of A. fumigatus should be studied independently within each geographical area. This situation may be the result of local selective pressure [31], including climate, environmental adaptation and therapeutic selection, coupled with low migration rates of $A$. fumigatus conidia.

MLEE provides a powerful tool for developing a better understanding of the local epidemiology of this fungus. However, these conclusions must be confirmed by other studies, using DNA typing methods with the same strains, to compare the results. These different techniques may clarify whether it is sufficient to type one isolate from each specimen to determine the strain responsible for invasive aspergillosis.

EBGA Network 'European concerted action: BMH 4 97-2481'; project leader R. Grillot.

R. Grillot, B. Lebeau, J. Burnod: Département de ParasitologieMycologie Médicale et Moléculaire, Relation Hôtes Agents Pathogènes, UPRES A CNRS 5082, Université Grenoble I, France.

N. Nolard, F. Symoens, K. Goens, S. Heinemann: Institut Scientifique de Santé Publique Louis Pasteur, Bruxelles, Belgium.

J-M. Bastide, M. Mallié, D. Castel, S. Bertout: Laboratoire d'Immunologie et Parasitologie, Université Montpellier I, France. F. Renaud, T. de Meeüs: Centre d'Étude sur le Polymorphisme des Micro-organismes, IRD, Montpellier, France.

J. Villard, A. Carlotti, F. Chaïb, A. Couble, A. Casoli: Laboratoire de Mycologie Fondamentale et Appliquée, Université Lyon I, France. M. A. Piens, E. Dannaoui, M. Perraud, M. F. Monier: Service de Parasitologie-Mycologie Médicale, Université Lyon I, France.

F. Chapuis: Laboratoire d'Information Médicale, Université Lyon I, France.

M. A. Viviani, A. M. Tortorano, A. Roverselli, M. Cogliati: Instituto de Igiene e Medicina Preventiva, Milan, Italy.

R. Barton, E. G. V. E. Evans, R. Ashbee, V. Hopwood: Department of Microbiology, University of Leeds, UK.

J. F. Meis, A. Voss, P. E. Verweij, J. P. Donnelly: Division of Bacteriology and Mycology, University of Nijmegen, The Netherlands.

P. M. Rath, R. Ansorg: Institut für Medezinische Mikrobiologie, der Universität Essen, Germany.

\section{References}

1. Denning DW. Invasive aspergillosis. Clin Infect Dis 1998; 26: 781-803.

2. Darras-Joly C, Lucet JC, Laissy JP et al. [Invasive pulmonary aspergillosis in AIDS.] Aspergillose pulmonaire invasive et SIDA. Pathol Biol 1998; 46: 416-417.

3. Singh N, Arnow PM, Bonham A et al. Invasive aspergillosis in liver transplant recipients in the 1990s. Transplantation 1997; 64: $716-720$

4. Chazalet V, Dubeaupuis J-P, Sarfati J et al. Molecular typing of environmental and patients isolates of Aspergillus fumigatus from various hospital settings. J Clin Microbiol 1998; 36: $1494-1500$.

5. Dubeaupuis J-P, Sarfati J, Chazalet V, Latgé J-P. Genetic diversity among clinical and environmental isolates of Aspergillus fumigatus. Infect Immun 1997; 65: 3080-3085.

6. Leenders A, van Belkum A, Janssen S et al. Molecular epidemiology of apparent outbreak of invasive aspergillosis in a hematology ward. J Clin Microbiol 1996; 34: 345-351.

7. Arnow PM, Sadigh M, Costas C, Weil D, Chudy R. Endemic and epidemic aspergillosis associated with in-hospital replication of Aspergillus organisms. J Infect Dis 1991; 164: 998-1002.

8. Manuel RJ, Kibbler CC. The epidemiology and prevention of invasive aspergillosis. J Hosp Infect 1998; 39: 95-109.

9. Rodriguez E, Symoens F, Mondon P et al. Combination of three typing methods for the molecular epidemiology of 
Aspergillus fumigatus infections. European Research Group on Biotype and Genotype of Aspergillus. J Med Microbiol 1999; 48: $181-194$.

10. Lin D, Lehmann PF, Harmory BH et al. Comparison of three typing methods for clinical and environmental isolates of Aspergillus fumigatus. $J$ Clin Microbiol 1995; 33: 1596-1601.

11. Loudon KW, Burnie JP, Coke AP, Matthews RC. Application of polymerase chain reaction to fingerprinting Aspergillus fumigatus by random amplification of polymorphic DNA. J Clin Microbiol 1993; 31: 1117-1121.

12. Mondon P, Brenier MP, Symoens F et al. Molecular typing of Aspergillus fumigatus strains by sequence-specific DNA primer (SSDP) analysis. FEMS Immunol Med Microbiol 1997; 17: 95-102.

13. Denning DW, Clemons KV, Hanson LH, Stevens DA. Restriction endonuclease analysis of total cellular DNA of Aspergillus fumigatus isolates of geographically and epidemiologically diverse origin. J Infect Dis 1990; 162: 1151-1158.

14. Burnie JP, Coke A, Matthews RC. Restriction endonuclease analysis of Aspergillus fumigatus DNA. J Clin Pathol 1992; 45: 324-327.

15. Pujol C, Reynes J, Renaud F et al. The yeast Candida albicans has a clonal mode of reproduction in the population of infected human immunodeficiency virus-positive patients. Proc Natl Acad Sci USA 1993; 90: 9456-9459.

16. Bertout S, Renaud F, Swinne D, Mallié M, Bastide J-M. Genetic multilocus studies of different strains of Cryptococcus neoformans: taxonomy and genetic structure. J Clin Microbiol 1999; 37: 715-720.

17. Brandt ME, Bragg SL, Pinner RW. Multilocus enzyme typing of Cryptococcus neoformans. J Clin Microbiol 1993; 31: 2819-2823.

18. Brandt ME, Hutwagner LC, Klug LA et al. Molecular subtype distribution of Cryptococcus neoformans in four areas of the United States. J Clin Microbiol 1996; 34: 912-917.

19. Rodriguez E, De Meëus T, Mallie M et al. Multicentric epidemiological study of Aspergillus fumigatus isolates by multilocus enzyme electrophoresis. J Clin Microbiol 1996; 34: 2559-2568.

20. Pasteur N, Pasteur G, Bonhomme F, Catalan J, Britton-
Davidian J. Manuel technique de génétique par électrophorèse des protéines. Paris, Lavoisier. 1987.

21. Nei M. Genetic distance between populations. Am Nat 1972; 106: $283-292$.

22. Nei M. Estimation of average heterozygosity and genetic distance from a small number of individuals. Genetics 1978; 89; $583-590$.

23. Rinyu E, Varga J, Ferenczy L. Phenotypic and genotypic analysis of variability in Aspergillus fumigatus. $J$ Clin Microbiol 1995; 33: 2567-2575.

24. Matsuda H, Kohno S, Maesaki H et al. Application of ubiquinone system and electrophoretic comparison of enzymes to identification of clinical isolates of Aspergillus fumigatus and several other species of Aspergillus. J Clin Microbiol 1992; 30: 1999-2005.

25. Radford SA, Johnson EM, Leeming JP et al. Molecular epidemiological study of Aspergillus fumigatus in a bone marrow transplantation unit by PCR amplification of ribosomal intergenic spacer sequences. J Clin Microbiol 1998; 36: 1294-1299.

26. Bart-Delabesse E, Humbert J-F, Delabesse E, Bretagne S. Microsatellite markers for typing Aspergillus fumigatus isolates. J Clin Microbiol 1998; 36: 2413-2418.

27. Birch M, Anderson MJ, Denning DW. Molecular typing of Aspergillus species. $J$ Hosp Infect 1995; 30 Suppl 1 : 339-351.

28. Brenier-Pinchart MP, Lebeau B, Devouassoux $\mathrm{G}$ et al. Aspergillus and lung transplant recipients: a mycologic and molecular epidemiologic study. J Heart Lung Transplant 1998; 17: $972-992$.

29. Le Guennec R, Reynes J, Mallié M, Pujol C, Janbon F, Bastide J-M. Fluconazole- and itraconazole-resistant Candida albicans strains from AIDS patients: multilocus enzyme electrophoresis analysis and antifugal susceptibilities. J Clin Microbiol 1995; 33: $3732-3737$

30. Reynes J, Pujol C, Moreau C et al. Simultaneous carriage of Candida albicans strains from HIV-infected patients with oral candidiasis: multilocus enzyme electrophoresis analysis. FEMS Microbiol Lett 1996; 137: 269-273.

31. Manly BJF. The statistics of natural selection on animal populations. Chapman and Hall, London. 1985. 